УДК 159.923

М. Є. Лещенко, ст. викладач

\title{
ТОЛЕРАНТНІСТЬ ЯК ЧИННИК ФОРМУВАННЯ УСПІШНОЇ ОСОБИСТОСТІ
}

Актуальність теми дослідження. Проблема фрормування успішної особистості набуває в сучасних умовах розвитку суспільства особливого значення. Дослідження проблеми толерантності та ії важливості викликано необхідністю побудови і організації нового суспільства, в якому всі особистості мають рівні права і можливості.

Постановка проблеми. При включенні у соціальну реальність, міжособистісну взаємодію постає проблема самореалізації в тому суспільстві, в якому існує особистість. Гармонійним існування стає тоді, коли самореалізація відбувається успішно. В сучасних умовах одним із чинників успішної самореалізації постає толерантність особистості.

Аналіз останніх досліджень $\boldsymbol{i}$ публікацій. Толерантність як якість особистості досліджується з різних боків: як особистісна риса, як категорія відносин, як суспільно значуща цінність, як важлива якість сучасного фрахівця (В. Байденко, А. Вербицький, І. Бех, Т. Болотіна, Б. Гершунський, О. Ю. Клепцова та інші).

Виділення недосліджених раніше частин загальної проблеми. В цілому, недостатня наукова розробка проблеми значення толерантності як особистісної якості успішної особистості визначила актуальність даного дослідження.

Постановка завдання. Завданнями даного дослідження $\epsilon$ визначення значення толерантності для успішності особистості, визначення критеріїв та проявів толерантності в діяльності та системі міжособистісних відносин та спілкування.

Виклад основного матеріалу. У статті визначено важливість толерантності для сучасної особистості. Проаналізовано зв'язок толерантності і успішності особистості. Визначено основні складові толерантності як якості особистості, такі як: когнітивний, емоційний та поведінковий. Охарактеризовано основні соціально-психологічні прояви толерантності особистості в системі ділових і міжособистісних стосунків.

Висновки. Проведене дослідження дозволяє зробити висновки, що толерантність як якість особистості має пронизувати всю діяльність та міжособистісні відносини суб'єктів суспільних відносин. Толерантність як якість особистості має бути наявною в комплексі базових ціннісних орієнтирів профресійно успішної особистості.

Ключові слова: особистість; толерантність; самореалізація; міжособистісні відносини; спілкування.

M. Ye. Leshchenko, Senior Lecturer

\section{TOLERANCE AS A FACTOR OF FORMING A SUCCESSFUL PERSONALITY}

Urgency of the research. The problem of the formation of a successful person acquires a special significance in modern conditions of development of society. The study of the problem of tolerance and its importance is due to the need to build and organize a new society in which all individuals have equal rights and opportunities.

Target setting. When person included in social reality, interpersonal interaction is the problem of self-realization in the society in which there is a person. Harmonious existence becomes when selfrealization is successful. In today's conditions, one of the factors of successful self-realization is the tolerance of the individual.

Actual scientific researches and issues analysis. Tolerance as a personality quality is investigated from different directions: as a personal trait, as a category of relationships, as a socially significant value, as an important quality of a modern specialist (V. Baidenko, A. Verbytskyi, I. Beh, T. Bolotina, B. Hershunskii, O. Kleptsova).

Uninvestigated parts of general matters defining. linsufficient scientific development of the problem of the value of tolerance as a personal quality of a successful personality determined the relevance of this study. 
The research objective. The objectives of this study are to determine the value of tolerance for the success of the individual, the definition of criteria and manifestations of tolerance in the activities and the system of interpersonal relations and communication.

The statement of basic materials. The article determines the importance of tolerance for the modern personality. The connection between tolerance and personality performance is analyzed. The basic components of tolerance as a personality quality are determined, such as: cognitive, emotional and behavioral. The basic social-psychological manifestations of personality tolerance in the system of business and interpersonal relations are characterized.

Conclusions. The conducted research allows us to conclude that tolerance as a personality's quality must permeate all activities and interpersonal relations of subjects of social relations. Tolerance as a person's quality must be available in a complex of basic value benchmarks of a professionally successful person.

Keywords: personality; tolerance; self-realization; interpersonal relationships; communication.

DOI: 10.25140/2412-1185-2019-1(13)-46-51

Актуальність теми дослідження. Проблема фрормування успішної особистості в сучасних умовах розвитку суспільства набуває особливого значення. Важливою складовою гармонійного існування і успішної самореалізації особистості постає розвиток толерантності, у зв'язку зі зростанням міжрасової, міжетнічної, релігійної нетерпимості та агресії. То ж дослідження проблеми толерантності та її важливості викликано необхідністю формування та розвитку суспільства, в якому всі особистості мають рівні права і можливості. Більша частина досліджень толерантності проводиться у руслі вивчення толерантності як якості особистості, що дозволяє успішно функціонувати в суспільстві загалом та в деяких конкретних сферах діяльності.

Постановка проблеми. Особистість людини формується і розвивається під впливом багатьох фракторів: об'єктивних і суб'єктивних, природних і суспільних, внутрішніх і зовнішніх, незалежних і залежних від волі та свідомості людей, які діють стихійно або відповідно до певних цілей, мети виховання. Під впливом соціальних та індивідуальних чинників фрормується світогляд, система цінностей та принципів життєдіяльності особистості. При включенні у соціальну реальність, міжособистісну взаємодію постає проблема самореалізації в тому суспільстві, в якому існує особистість. Гармонійним існування стає тоді, коли самореалізація відбувається успішно. В сучасних умовах одним із чинників успішної самореалізації постає толерантність особистості.

3 кінця минулого століття в західній науці постала проблема толерантності як одного 3 принципів організації людського суспільства. Толерантність та особливості їі формування в останній час стає предметом численних психологічних, соціологічних та психолого-педагогічних досліджень. В сучасному суспільстві толерантність визначається як здатність без агресії сприймати думки, поведінку, фрорми самовираження та спосіб життя іншої людини, які відрізняються від власних. Толерантність як прояв особистості займає значне місце у діяльності фахівців не тільки в сфрері «людина-людина», а і в багатьох інших сфрерах, i, особливо, у сфері міжособистісного спілкування і взаємодії.

Аналіз останніх досліджень і публікацій. Толерантність особистості стала предметом дослідження різноманітних галузей наукового знання. Аналіз літератури показує наявність досліджень, присвячених: проблемі толерантності як важливої якості сучасного фахівця (В. Байденко, А. Вербицький, І. Дінисов, А. Заховаєва, І. Ісаєва, М. Пальцев); формуванню толерантності як суспільно значущої цінності (В. Береговий, І. Бех, Т. Болотіна, Б. Гершунський, О. Грива, О. Клєпцова, І. Крутова, В. Лекторський, М. Міріманова, Р. Ріердон, П. Степанов); місцю толерантності у процесі набуття особистісної цілісності (О. Г. Асмолов, Є. Ф. Казаков, В. А. Тишков); специфріці міжетнічної толерантності (Н. М. Лебедєва, В. М. Павленко, М. І. Пірен, Г. У. Солдатова, Т. Г. Стефраненко, Т. А. Устименко); толерантності як категорії відносин (О. Ю. Клепцова, В. Г. Маралов, В. А. Ситаров); толерантності як особистісної риси (С. К. Бондирєва, Д. В. Колесов); рис комунікативної толерантності (В. В. Бойко). Розробляються прикладні аспекти фрормування толерантної свідомості О. О. Савченко, Л. Д. Шайгерова, О. Д. Шарова).

Виділення недосліджених раніше частин загальної проблеми. В цілому, недостатня наукова розробка проблеми значення толерантності як особистісної якості успішної особистості 
визначила актуальність даного дослідження.

Висвітлення даної проблеми є результатом дослідження в рамках розробки наукової теми «Соціальні та психологічні умови формування психологічної стійкості особистості у важких та кризових ситуаціях»

Постановка завдання. Завданнями даного дослідження $€$ визначення значення толерантності для успішності особистості, визначення критеріїв та проявів толерантності в діяльності та системі міжособистісних відносин та спілкування.

Виклад основного матеріалу. Серед основних проблем розвитку особистості важливе місце належить категорії успішності, ставлення людини до власного успіху, оскільки успіх як психологічне явище пов'язаний із соціальною природою людини, з виявом її сутнісного начала.

Успішність це динамічний процес, невідривно пов'язаний з діяльністю та міжособистісною взаємодією. Проаналізувавши літературні джерела, успішність можна визначити як загальне, системне явище, що супроводжується життєвим досвідом і формується завдяки позитивному мисленню та способу життя особистості як її структурної складової, в основі якої лежить мета досягнення успіху через цілеспрямовану діяльність і прагнення розвиватися гармонійно в усіх сорерах суспільного життя.

Формування і розвиток особистості відбувається невід'ємно від соціуму. Особистісний і професійний розвиток особистості - це складне, багаторівневе та багатофракторне явище. Важливою детермінантою розвитку $є$ самоактуалізація особистості, що розглядається як важливий компонент успішності суб'єкта діяльності. Формування успішної особистості вимагає не тільки формування різноманітних здібностей і інтересів, які відповідають різним сферам життєдіяльності особистості. Успішність залежить і від реалізації себе в системі міжособистісних відносин та тих цінностей і принципів, якими керується особистість. Поняття самоактуалізації містить у собі безперервний розвиток творчого і духовного потенціалу людини, максимальну реалізацію всіх її можливостей, адекватне сприйняття оточуючих, високий рівень психічного здоров'я та моральності. Значне місце в системі цінностей особистості, які визначають міжособистісні відносини, має займати толерантність.

Під толерантністю в соціально-фрілософському сенсі цього поняття слід розуміти певну соціальну якість міжлюдських відносин, а також окремих індивідів, їхніх згромаджень і груп, що характеризується установкою на доброзичливе сприйняття «іншого», бажання не тільки зрозуміти, але і, наскільки можливо, прийняти традиції, культуру, переконання, вірування, інтереси, цінності цього «іншого». Толерантним ставленням називається таке, коли людина прагне досягти взаєморозуміння та реалізації власних цілей шляхом досягнення узгодженості своїх дій з діями інших людей, без застосування будь-яких заходів насильства, примусу та тиску, а лише за допомогою взаємодискусій, переконання й обопільною кореляцією поведінкових актів і дій.

У перекладі толерантність означає «терпимість», і напевно, більш глибоко зміст цього слова виявляється через дієслово «терпіти». Новий тлумачний словник української мови виділяє такі його основні значення: «витримувати», «миритися 3 чим-небудь неприємним, важким, небажаним»; «поблажливо, вибачливо ставитись до когось, чогось, до чиїхось провин, недоліків» [1]. Як бачимо, йдеться не про індиферентність чи байдужість, а про свідомий прояв вольових зусиль з боку людини у визначенні її певного ставлення до негативних подразнень і впливів ззовні, що проявляється у свідомому примиренні (до певної межі) з ними.

Потреба жити в цивілізованому суспільстві, прагнення бути носієм передових демократичних та загальнолюдських цінностей водночас означає потребу в толерантній свідомості та толерантній поведінці.

Толерантність передбачає прийняття іншого таким, яким він є. І подібно до того, як психолог, не ідентифікуючись із клієнтом, приймає його і слідує за ним, толерантність передбачає такий же уявний рух до розуміння. При цьому зовсім не відмовляючись від власної позиції, але і не нав'язуючи її партнерові. Толерантність забезпечує мирне співіснування представників різних культур та народів, орієнтує відносини людей на дотримання рівноправності та поваги.

Повага до людської гідності фрормується і проявляється через усвідомлення приналежності даного індивіда до людського роду, цілісності та недоторканості його невідчужуваних природних прав, які $€$ рівноцінними за своїм значенням з правами усіх інших людей. Така повага вкрай ускладнює схиляння індивіда до думок та дій агресивного, людиноненависницького спрямування. 
Толерантність постає як визнання прав іншого і, тим самим, набуття дружелюбності, миролюбивості і здатності сприймати іншого як собі подібного, рівного, що претендує на розуміння, співчуття, прийняття, а не як чужорідного, що претендує на відторгнення.

Толерантність проявляється через здатність індивіда самостійно приборкати і власноруч спрямувати у напрямку більшої терпимості та виваженості свої оцінки, а у подальшому - вчинки та дії стосовно «іншого», незважаючи на опір, який може чинити зсередини людини її «Я».

Толерантність - це чеснота: мистецтво жити у світі різних людей та ідей, здатність мати права та свободи, при цьому, не порушуючи прав і свобод інших людей. Водночас толерантність - це не поступка, поблажливість чи потурання, а активна життєва позиція на основі визнання іншого.

Одна з найбільш відомих концепцій толерантності належить Г. Олпорту. на його думку, толерантна особистість в загальному вигляді постає як особа, яка дружньо ставиться до інших незалежно від групової приналежності кожного з них [2]. Толерантна особистість має ряд характеристик, які було визначено Олпортом:

- прихильність до інших;

- поблажливість;

- терпіння;

- почуття гумору;

- чуйність;

- довіра;

- альтруїзм;

- терпимість до відмінностей;

- вміння володіти собою;

- доброзичливість;

- вміння не засуджувати інших;

- гуманізм;

- вміння слухати;

- допитливість, здатність до співпереживання.

Складовими структури толерантності і критеріями гуманістичної зрілості та сформованості особистості виступають її інтегративні характеристики - знання, переконання, ідеали, цінності, емоційні стани, вольові установки стосовно позитивного сприйняття людини, її невідчужуваної гідності, прав, свободи, поваги до її вибору, до самостійного життєвого укладу, самобутньої культури, мови, побуту. Крім того, такими показниками толерантної спрямованості можуть бути критичність мислення і протидія стереотипам, проявам ксенофобії, деструктивного націоналізму, політичного екстремізму, расовим, статевим та іншим забобонам. Свою остаточну якісну оформленість толерантність набуває в реальній здатності особистості до саморегуляції у вербальній та невербальній поведінці в умовах її взаємодії з суспільним оточенням.

Сформована толерантність допомагає визначитись особистості як суб'єкту спілкування, що в свою чергу дозволяє ії більш успішно, більш результативно здійснювати різноманітні за характером суспільні взаємодії, реалізовувати більш широкий спектр соціальних ролей і функцій.

Толерантність як ставлення породжує довіру, готовність (установку) до компромісу (співробітництва), радість, комунікабельність, дружелюбність.

Толерантність це завжди свідомий вибір і $€$ атрибутом зрілої особистості. Він полягає у виборі ставлення особистості до того, що відрізняється від суспільних чи ії̈ особистих норм та ідеалів. Сутність цього френомена зводиться до утвердження автономії індивіда, тобто положення, що лише сама особистість може вирішувати, який образ життя або яка релігійна, політична чи моральна та інші теорія є для неї найкращою.

Як зазначає В. М. Павленко, індивідуально-психологічний аспект вивчення толерантності спрямований на психологічні особливості, що допомагають особистості розбудовувати позитивні конструктивні стосунки як з оточуючими, так у системі власної Я-концепції. Таке широке визначення відповідного аспекту толерантності свідчить про різноманіття залучених у систему толерантності індивідуально-психологічних складових, що мають когнітивний, афективний і поведінковий характер [4].

Когнітивний компонент толерантності полягає в усвідомленні й прийнятті людиною складності, багатомірності - як самої життєвої реальності, так і варіативності її сприйняття, розуміння й оцінювання різними людьми, а також відносності, неповноти й суб'єктивності 
(щонайменше - часткової) власних уявлень і своєї картини світу. Толерантність у когнітивному «вимірі» найяскравіше проявляється саме в ситуаціях протиріч - при розбіжності думок, зіткненні поглядів - і дозволяє розглядати цю розбіжність як прояв плюралізму, багатства індивідуального сприйняття та інтерпретацій.

У якості основної складової емоційного компонента може бути названа емпатія. Однією 3 головних функцій емпатії в системі толерантності $€$ компенсація як можливих розбіжностей між співрозмовниками в когнітивній або поведінковій площинах (індивідуально-психологічний рівень), так і недостатньої нервово-психічної стійкості (психофрізіологічний рівень), що у свою чергу перешкоджає переростанню їх взаємодії в міжособистісне протистояння й нетерпимість.

Одним із чинників толерантності можна вважати рівень розвитку емоційного інтелекту. Вміння розуміти і керувати власними і чужими емоційними станами, безумовно, має відігравати свою роль як у збереженні емоційної рівноваги, позитивного характеру діяльності, так і у встановлені гармонійних, продуктивних стосунків з іншими.

Вміння долати небажані емоційні стани, зберігати продуктивний характер діяльності за різних обставин, розуміти емоції інших та підтримувати з ними позитивні стосунки зближують емоційний інтелект з різними компонентами системи толерантності. Отже, емоційний інтелект і така його складова, як емпатія (що може розглядатися і окремо), можуть розглядатися як емоційні передумови або індикатори толерантності.

До поведінкової толерантності належить велика кількість конкретних умінь і здібностей, серед яких можна виділити:

- здатність до толерантного висловлення й відстоювання власної позиції як точки зору (Я-Висловлювання тощо);

- готовність до толерантного ставлення до висловлювань інших (сприйняття думок і оцінок інших людей як вираження їх точки зору, що має право на існування - незалежно від ступеню розбіжності з власними поглядами);

- здатність до «взаємодії різномислячих» і вміння домовлятися (узгоджувати позиції, досягати компроміс і консенсус);

- толерантна поведінка в напружених ситуаціях (при відмінностях в точках зору, зіткненні думок або оцінок).

Психофрізіологічний аспект розгляду толерантності звертається до стійкості до зовнішніх впливів, здатності зберігати стан нервово-психічної рівноваги, стабільність при дії стресорів і чинників, що фруструють. Одним з найбільш релевантних репрезентантів відповідної складової толерантності $€$ нервово-психічна стійкість, до розгляду якої ми і перейдемо.

Нервово-психічна стійкість характеризується емоційною незворушністю, невразливістю, тобто нереагуванням людини на подразники, ситуації. При розгляді нервово-психічної стійкості мова йде насамперед про психофізіологічні аспекти толерантності - фактори та складові, що забезпечують витривалість психіки на психофрізіологічному, нейропсихологічному рівні, відбиваючи збалансованість роботи нервової системи, механізмів забезпечення функціонування психіки.

Толерантна особистість поєднує важливі характеристики, що відображають психолого-етичні сторони людських стосунків, а саме [3]:

- гуманність - увага до самобутнього внутрішнього світу людини, віру у його добре начало, людяність міжособистісних стосунків, відмову від форм придушення гідності людини;

- рефлективність - глибинне знання особливостей людини, її достоїнств і недоліків, установлення їх відповідно до толерантного світосприйняття;

- свобода - дисципліна та обов'язок, несприйняття насильницьких наказів і заборон, що здатне привести до правильних законів, авторитет яких - гарантія їх реалізації у життя;

- відповідальність - прояв внутрішньої сили в ситуації прийняття рішення, його якісного виконання на основі варіативного підходу та системи особистісних вимог;

- захищеність - гарантія розуміння і підтримки, відчуття безпеки й об'єднання з іншими людьми в протистоянні пагубному впливу соціуму;

- гнучкість - уміння залежно від складу учасників подій і обставин, що склалися, приймати рішення; вибудовування системи стосунків на основі володіння повноцінною інформацією;

- самовладання - володіння собою, управління емоціями, вчинками; варіативність багатомірний підхід до оцінки навколишнього життя і прийняття адекватних рішень щодо 
обставин, які склалися;

- перцепція - вміння підмічати й виділяти різні властивості людей, проникати в їхній внутрішній світ;

- емпатія - співпереживання проблемам інших людей, емоційна оцінка подій;

- почуття гумору - іронічне ставлення до безглуздості обставин, непродуманих дій, вміння посміятися над собою.

Висновки. В сучасних умовах існування особистості у середовищі особистостей, які маєть багато різних особливостей (етнічні, психологічні, фрізичні тощо) постає важливим питання толерантності до цих особливостей. Для успішної самореалізації в діловій і міжособистісній сорері важливо зберігати стан рівноваги і позитивний характер діяльності, а також підтримувати гармонійні продуктивні стосунки з іншими. Отже, в даний час має велике значення усвідомлення важливості феномена толерантності для нашого суспільства. Толерантність - цінність і соціальна норма громадянського суспільства, що виявляється у праві всіх громадян бути різними, у повазі до культурної різноманітності, забезпечує гармонію у відносинах різних культур. Проведене дослідження дозволяє зробити висновки, що толерантність як якість особистості має пронизувати всю діяльність та міжособистісні відносини суб'єктів суспільних відносин. Толерантність як якість особистості має бути наявною в комплексі базових ціннісних орієнтирів професійно успішної особистості.

\section{Література}

1. Новий тлумачний словник української мови : в трьох томах / [укл. В. Яременко, О. Сліпушко]. - II вид. - К. : Аконіт, 2005. - Т. 3. - 2005. П-Я. -928 с

2. Олпорт, Г. У. Природа предубеждения / Г. У. Олпорт // Век толерантности. - 2003. - Вып. 5. - С. 43.

3. Орловська, О. В. Толерантність та її сутнісні характеристики [Електронний ресурс] / О. В. Орловська.- Режим доступу : http://www.irbis-nbuv.gov.ua/cgi-bin/irbis_nbuv/cgiirbis_64.exe?C21COM=2\&I21DBN=UJRN\&P21DBN=UJRN\& IMAGE_FILE_DOWNLOAD=1\&Image_file_name=PDF/Znpkhist_2012_5_37.pdf.

4. Павленко, В. М. Психологія толерантності особистості (на матеріалі дослідження студентів): монографрія / В. М. Павленко, М. М. Мельничук; авт. післямови проф. В. Ф. Моргун. - Полтава : ФОП Мирон І. А., 2014. - 244 с.

\section{Reference}

1. Novyi tlumachnyi slovnyk ukrainskoi movy [New explanatory dictionary of the Ukrainian language]. (2005). (Vols. 1-3). Kyiv: Akonit [in Ukrainian].

2. Ollport, H. U. (2003). Priroda predubezhdenyia [Nature of prejudice]. Vek tolerantnosti - Age of tolerance, 5, 43 [in Russian].

3. Orlovska, O. V. (2012). Tolerantnist ta yii sutnisni kharakterystyky [Tolerance and its essential characteristics]. www.irbis-nbuv.gov.ua. Retrieved from http://www.irbis-nbuv.gov.ua/cgi-bin/irbis nbuv/cgiirbis 64.exe?C21COM=2\&/21DBN= UJRN\&P21DBN=UJRN\&IMAGE_FILE_DOWNLOAD=1\&Image_file_name=PDF/Znpkhist_2012_5_37.pdf [in Ukrainian].

4. Pavlenko, V. M. (2014). Psykholohiia tolerantnosti osobystosti (na materiali doslidzhennia studentiv) [Psykhology of tolerance of personality (on the student research material)]. Poltava: FOP Myron I. A. [in Ukrainian].

Надійшла 06.06.2019

Бібліографічний опис для цитування:

Лещенко, М. Є. Толерантність як чинник фрормування успішної особистості / М. Є. Лещенко // Проблеми соціальної роботи: фрілософрія, психологія, соціологія. - 2019. - № 1 (13) - С. 46-51. 